\title{
Review \\ Recent Progress in Homogeneous Catalytic Dehydrogenation of Formic Acid
}

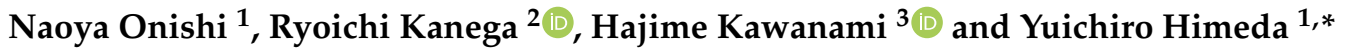 \\ 1 Global Zero Emission Research Center, National Institute of Advanced Industrial Science and Technology, \\ Tsukuba West, 16-1 Onogawa, Tsukuba 305-8569, Ibaraki, Japan; n.onishi@aist.go.jp \\ 2 Research Institute of Energy Conservation, National Institute of Advanced Industrial Science and Technology, \\ Tsukuba 305-8565, Ibaraki, Japan; r-kanega@aist.go.jp \\ 3 Interdisciplinary Research Center for Catalytic Chemistry, National Institute of Advanced Industrial Science \\ and Technology, Central 5, 1-1-1 Higashi, Tsukuba 305-8565, Ibaraki, Japan; h-kawanami@aist.go.jp \\ * Correspondence: himeda.y@aist.go.jp
}

Citation: Onishi, N.; Kanega, R.; Kawanami, H.; Himeda, Y. Recent Progress in Homogeneous Catalytic Dehydrogenation of Formic Acid. Molecules 2022, 27, 455.

https://doi.org/10.3390/ molecules27020455

Academic Editors: Maurizio Peruzzini and Luca Gonsalvi

Received: 17 November 2021 Accepted: 8 January 2022

Published: 11 January 2022

Publisher's Note: MDPI stays neutral with regard to jurisdictional claims in published maps and institutional affiliations.

Copyright: (C) 2022 by the authors. Licensee MDPI, Basel, Switzerland. This article is an open access article distributed under the terms and conditions of the Creative Commons Attribution (CC BY) license (https:// creativecommons.org/licenses/by/ $4.0 /)$.

\begin{abstract}
Recently, there has been a strong demand for technologies that use hydrogen as an energy carrier, instead of fossil fuels. Hence, new and effective hydrogen storage technologies are attracting increasing attention. Formic acid (FA) is considered an effective liquid chemical for hydrogen storage because it is easier to handle than solid or gaseous materials. This review presents recent advances in research into the development of homogeneous catalysts, primarily focusing on hydrogen generation by FA dehydrogenation. Notably, this review will aid in the development of useful catalysts, thereby accelerating the transition to a hydrogen-based society.
\end{abstract}

Keywords: formic acid; homogenous catalysts; hydrogen production

\section{Introduction}

Technological development aimed at building a society that uses hydrogen, which can be used with low environmental load and high efficiency, as an energy medium is urgently required. However, because hydrogen gas is flammable, safety issues involving its storage and transportation limit its use as a fuel [1]. In particular, the research and development of hydrogen carriers for efficiently storing and transporting hydrogen with a low volumetric energy density has become active. In this regard, ammonia [2], ammonia borane [3], and formic acid (FA) [4] have recently been gaining considerable attention. In addition, to make widespread use of hydrogen energy, it is necessary to reduce the cost of supplying hydrogen at hydrogen stations.

Researchers have focused on a hydrogen storage system using FA as a hydrogen carrier. FA is a liquid, containing $4.4 \mathrm{wt} \%$ hydrogen, and has slight toxicity to the human body and environment. Another advantage is that carbon dioxide, which is inexpensive and present in large quantities, is used as a raw material. Furthermore, the free energy required for mutual conversion with carbon dioxide in an aqueous solution is $-4 \mathrm{~kJ} / \mathrm{mol}$, significantly smaller than that of other hydrogen carriers. Therefore, the energy loss required for substance conversion, associated with hydrogen storage and release, can be significantly reduced when FA is used as a hydrogen carrier [5]. In addition, unlike the reactions of other hydrogen carriers, the FA dehydrogenation (FADH) proceeds, even under pressurized conditions; hence, it is possible to supply compressed hydrogen gas. A high-performance homogeneous catalyst is required to utilize FA, which exhibits such excellent properties, as a hydrogen carrier.

In FADH, one possible side reaction (Equation (1) and dehydration) can occur. Generally, CO contaminates fuel cells; thus, a highly active and selective catalyst for FADH (Equation (2)) is strongly desired. Various heterogeneous catalysts for FADH have been studied. However, the activation of these catalysts, such as Pd-based catalysts, usually 
requires a high temperature, resulting in $\mathrm{CO}$ contamination. $\mathrm{CO}$ is a well-known poison to the catalyst in the proton exchange membrane (PEM) fuel cells [6]. In addition, these catalysts have low durability and are difficult to perform for long periods of time. Currently, homogeneous catalysts, such as FADH catalysts, are more advantageous than heterogeneous catalysts because they cause less $\mathrm{CO}$ contamination and perform at a lower reaction temperature. Coffey performed pioneering work using various homogenous catalysts for FADH [7]. A series of $\mathrm{Pt}$ [8], $\mathrm{Ru}$ [9], and $\mathrm{Rh}$ [10] complexes were evaluated, and the iridium complex $\mathrm{IrH}_{2} \mathrm{Cl}\left(\mathrm{PPh}_{3}\right)_{3}$ gave the highest TOF $\left(1187 \mathrm{~h}^{-1}\right)$. Although $\mathrm{Pt}$ and $\mathrm{Rh}$ complexes were tested for FADH, their catalytic activities and durabilities were low. However, in 2008, a selective FADH, using an effective catalyst, was reported under mild conditions, and the development of homogeneous catalysts became active. This paper summarizes the homogeneous catalysts for FADH and consists of two sections with precious and non-precious metal catalysts.

$$
\begin{gathered}
\mathrm{HCOOH} \rightarrow \mathrm{H}_{2} \mathrm{O}+\mathrm{CO} \\
\mathrm{HCOOH} \rightarrow \mathrm{H}_{2}+\mathrm{CO}_{2}
\end{gathered}
$$

\section{Precious Metal Catalysts for FADH}

In 2008, Beller et al. reported a selective FADH, catalyzed by commercially available ruthenium precursors, including $\left[\mathrm{RuCl}_{2}\left(\mathrm{PPh}_{3}\right)_{3}\right],\left[\mathrm{RuCl}_{2}(\mathrm{p} \text {-cymene })\right]_{2}, \mathrm{RuCl}_{2}\left(\mathrm{PPh}_{3}\right)_{3}$, $\left[\mathrm{RuCl}_{3} \text { (benzene) }\right]_{2}$, and $\mathrm{RuBr}_{3} \times \mathrm{H}_{2} \mathrm{O}$ with triphenylphosphine-type ligands in $\mathrm{FA} / \mathrm{NEt}_{3}$ azeotropic solutions [11]. The generated gases contained $\mathrm{H}_{2} / \mathrm{CO}_{2}$, without any $\mathrm{CO}$ contamination. Additionally, by connecting the reactor to a fuel cell, the authors provided evidence that the hydrogen produced under these conditions could be used to generate electricity directly, without removing CO. No fuel cell catalyst poisoning was observed when all the trace amine vapors were removed from the hydrogen with an activated carbon filter. This process uses the $\left[\mathrm{RuCl}_{3} \text { (benzene) }\right]_{2}$ and $N, N$-dimethyl- $n$-hexylamine as an optimized catalytic system. Further, 1,2-bis(diphenylphosphino)ethane is used in the setup for continuous hydrogen production. Simultaneous to the discovery by Beller, Laurenczy et al. also reported an effective FADH catalyst. $\mathrm{Ru}$ precursor, $\left[\mathrm{Ru}\left(\mathrm{H}_{2} \mathrm{O}\right)_{6}\right]^{2+}$ and two equivalents of trisulfonated triphenylphosphine could catalyze FADH in $90 \mathrm{~h}$ to generate $\mathrm{H}_{2} / \mathrm{CO}_{2}$ with TON of up to 4000 [12]. Various precious metal catalysts have been developed since the reports of Beller and Laurenczy (Figure 1, Table 1).

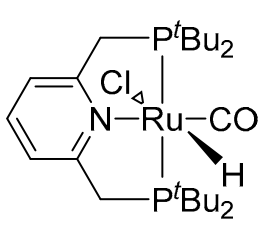

Ru-1

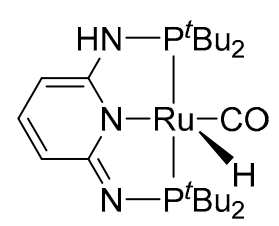

Ru-2

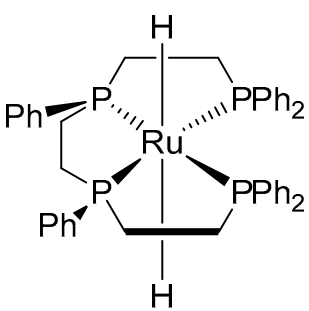

Ru-3

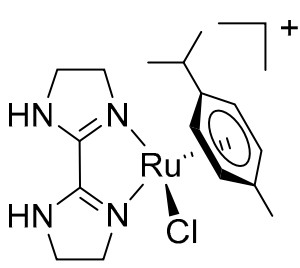

Ru-4

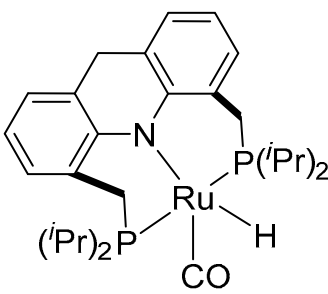

Ru-5

Figure 1. Ru catalysts for FADH. 
Table 1. Selected precious metal catalysts for FADH.

\begin{tabular}{ccccccc}
\hline Catalyst & Temp., $^{\circ} \mathbf{C}$ & Solvent & Additive & TON & TOF, $\mathbf{h}^{-\mathbf{1}}$ & Ref. \\
\hline Ru-1 & 90 & $\mathrm{DMF}$ & $\mathrm{NEt}_{3}$ & 706,500 & 257,000 & {$[13]$} \\
$\mathbf{R u}-\mathbf{2}$ & 90 & $\mathrm{DMSO}$ & $\mathrm{NEt}_{3}$ & $1,100,000$ & 7330 & {$[14]$} \\
$\mathbf{R u}-\mathbf{3}$ & 60 & $\mathrm{PC}$ & $\mathrm{DMOA}$ & 220,000 & - & {$[15]$} \\
$\mathbf{R u}-\mathbf{4}$ & 90 & $\mathrm{H}_{2} \mathrm{O}$ & $\mathrm{HCOONa}$ & 350,000 & 12,000 & {$[16]$} \\
$\mathbf{R u}-\mathbf{5}$ & 95 & - & - & $1,700,000$ & 3067 & {$[17]$} \\
Ir-1 & 60 & $\mathrm{H}_{2} \mathrm{O}$ & - & 5000 & 2400 & {$[18]$} \\
Ir-2 & 60 & $\mathrm{H}_{2} \mathrm{O}$ & $\mathrm{HCOONa}$ & 5300 & 5440 & {$[19]$} \\
Ir-3 & 80 & $\mathrm{H}_{2} \mathrm{O}$ & $\mathrm{HCOONa}$ & 308,000 & 158,000 & {$[20]$} \\
Ir-4 & 80 & $\mathrm{H}_{2} \mathrm{O}$ & - & 10,000 & 34,000 & {$[21]$} \\
Ir-5 & 100 & $\mathrm{H}_{2} \mathrm{O}$ & $\mathrm{HCOONa}$ & 68,000 & 322,000 & {$[22]$} \\
Ir-6 & 90 & $\mathrm{H}_{2} \mathrm{O}$ & - & 47,000 & 487,500 & {$[23]$} \\
Ir-7 & 50 & $\mathrm{H}_{2} \mathrm{O}$ & - & $2,000,000$ & 7340 & {$[24]$} \\
Ir-8 & 70 & $\mathrm{H}_{2} \mathrm{O}$ & - & $10,000,000$ & - & {$[24]$} \\
Ir-9 & 90 & $\mathrm{H}_{2} \mathrm{O}$ & - & $3,900,000$ & 65,000 & {$[25]$} \\
Ir-10 & 90 & - & $\mathrm{HCOONa}$ & 121,000 & 674,000 & {$[26]$} \\
Ir-11 & 60 & $\mathrm{H}_{2} \mathrm{O}$ & - & 90 & 31 & {$[27]$} \\
Ir-12 & 35 & $\mathrm{DME}$ & - & 2340 & 6090 & {$[28]$} \\
Ir-13 & 90 & $\mathrm{H}_{2} \mathrm{O}$ & & 3300 & 3300 & {$[29]$} \\
Ir-14 & 85 & toluene & - & 3090 & - & {$[30]$} \\
Ir-15 & 60 & $\mathrm{DME}$ & $\mathrm{HCOONa-}$ & 500,000 & 20,000 & {$[31]$} \\
\hline
\end{tabular}

Pincer ligands are used in various catalysts because they provide high thermal stability [13]. Various pincer catalysts have also been developed for FADH. In 2014, Pidko et al. reported a well-defined Ru complex (Ru-1), with a PNP-pincer ligand for FADH, with a TOF of up to $257,000 \mathrm{~h}^{-1}$ and TON of 706,500 (DMF/NEt 3 , at $90{ }^{\circ} \mathrm{C}$ ), without a CO byproduct [13]. Because the catalyst performed the hydrogenation of $\mathrm{CO}_{2}$ to formate with high activity, the researchers achieved 10 consecutive $\mathrm{H}_{2}$ storage/generation cycles in a DMF/DBU solvent mixture over 1 week. Huang and Zheng et al. studied a Ru complex (Ru-2) with a PNP-pincer ligand, a dearomatized pyridine moiety with an imine arm [14]. Using this catalyst for FADH, a TON of 95,000 was obtained under mild conditions without any additive $\left(50^{\circ} \mathrm{C}\right.$, in DMSO), with a TOF of $2380 \mathrm{~h}^{-1}$. Furthermore, the catalytic activity was improved by adding a base compound, such as $\mathrm{NEt}_{3}$, at $90{ }^{\circ} \mathrm{C}$ with a TOF of $7330 \mathrm{~h}^{-1}$ and TON of 1100,000 in $150 \mathrm{~h}$. The authors studied the reaction mechanism by ${ }^{1} \mathrm{H}$ NMR analysis and suggested that the catalysis entailed the ligand aromatization-dearomatization process. In the first step, protonation (aromatization) of the imine nitrogen occurs, and the formate coordinates to the metal center. Subsequently, a dihydride complex is generated via $\mathrm{CO}_{2}$ elimination. Finally, the dihydride complex eliminates $\mathrm{H}_{2}$ gas via ligand dearomatization, leading to regeneration of the dearomatized pincer complex (Figure 2).

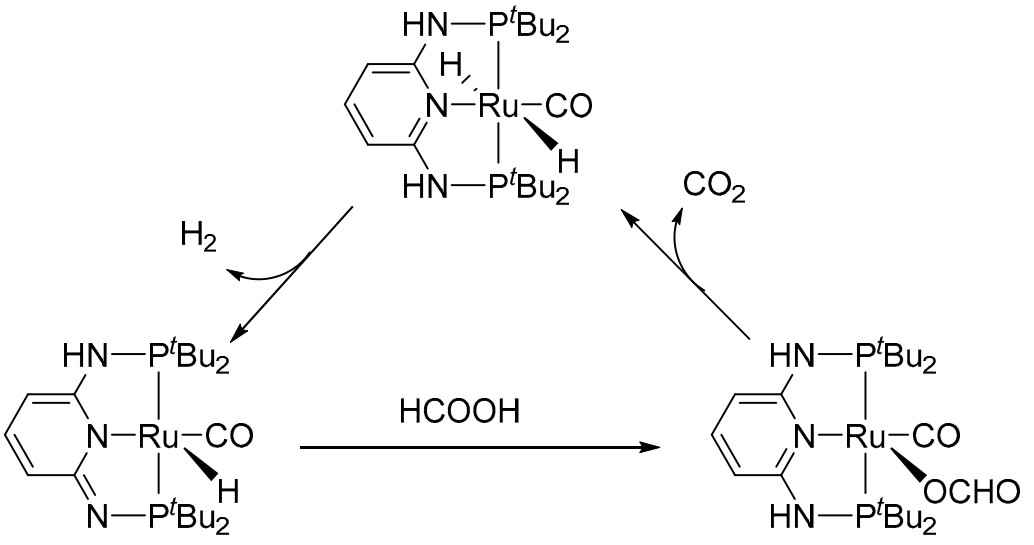

Ru-2

Figure 2. Proposed mechanism for FADH catalyzed by Ru-2. 
Gonsalvi et al. developed an in-situ catalyst system for FADH, with a Ru complex (Ru-3) in the presence of a linear tetraphos ligand, P4 (1,1,4,7,10,10-hexaphenyl1,4,7,10-tetraphosphadecane) [15]. Among the two stereoisomers (Figure 3), the meso isomer was more effective for $\mathrm{Ru}$ catalysis than the rac-isomer. The authors investigated the catalyst durability in a long-term reaction, using a pump to feed an FA solution. $\left[\mathrm{RuCl}_{2} \text { (benzene) }\right]_{2} /$ meso-P4 (1/2) was employed (conditions: FA/DMOA (11:10) $5.0 \mathrm{~mL}$, PC $1.0 \mathrm{~mL}$ at $60^{\circ} \mathrm{C}$ ), and the catalyst mixture was recyclable 11 times, with a total TON of 220000 in $48 \mathrm{~h}$. However, rac-P4 could be recycled for only eight consecutive runs when it was used as a ligand under similar reaction conditions, although the mixture showed catalytic activity. No $\mathrm{CO}$ was detected in the produced $\mathrm{H}_{2} / \mathrm{CO}_{2}$ gas. This gas can be supplied directly to the $\mathrm{H}_{2} / \mathrm{O}_{2}$ PEM fuel cell to generate electricity. The fuel cell could generate a stable current to drive the fan, owing to the continuous gas supply.<smiles>Pc1ccccc1</smiles>

rac-P4<smiles>Pc1cccc(P(CCP(P)c2ccccc2)CCP(c2ccccc2)c2ccccc2)c1P</smiles>

meso-P4

Figure 3. Structures of rac- and meso-P4.

Subsequently, Huang et al. developed a Ru complex (Ru-4) with a bisimidazoline ligand for FADH in $\mathrm{H}_{2} \mathrm{O}$ because $\mathrm{Li}$ et al. demonstrated that the bisimidazoline ligand of an Ir complex was effective for FADH [16,32]. Although the catalytic activity of the Ru complex was lower than that of the Ir analog, a TOF of $12,000 \mathrm{~h}^{-1}$ and TON of 350,000 were achieved with $\mathrm{HCOONa}$ at $90^{\circ} \mathrm{C}$. In addition, highly pressurized $\mathrm{H}_{2} / \mathrm{CO}_{2}(24 \mathrm{MPa})$ was produced, without $\mathrm{CO}$ contamination. Recently, Milstein et al. obtained a high TON of more than 1.7 million and TOF of $3067 \mathrm{~h}^{-1}$, with Ru-5 bearing a $9 \mathrm{H}$-acridine pincer ligand as the FADH catalyst at $95{ }^{\circ} \mathrm{C}$ [17]. The characteristic feature of this catalytic system is that it maintains catalytic activity for two months and has high durability in a neat solvent.

Various iridium catalysts are also reported to be effective (Figure 4). In 2009, Himeda discovered that $\mathrm{Cp}^{*} \mathrm{Ir}$ catalysts with $\mathrm{N}^{\wedge} \mathrm{N}$-bidentate ligands, such as 2,2'-bipyridine (BPy), catalyzed FADH [18]. This type of catalyst, which is water-soluble, is catalytically active toward aqueous FADH without organic bases, such as amine derivatives. Himeda et al. found that the electron-donating property of the ligand affected the improvement of catalytic performance. For example, Cp*Ir catalysts bearing 4,4'-dihydroxy-bipyridine (Ir-1) showed 80-fold higher catalytic activity than the BPy catalyst for FADH. Next, when the $\mathrm{OH}$ group on the ligand was moved to the ortho position, interesting findings were obtained from the viewpoint of the reaction mechanism [19,33]. First, the $\mathrm{pH}$ dependence of the catalytic activity differed greatly, depending on the substitution position of the $\mathrm{OH}$ group. Although the catalytic performances of Ir-1 and Ir-2 were almost similar under acidic conditions ( $\mathrm{pH} 1.7)$, the catalytic activity of Ir-1 decreased as the $\mathrm{pH}$ increased. In contrast, Ir-2 showed the maximum TOF $\left(5440 \mathrm{~h}^{-1}\right)$ at $\mathrm{pH}$ 3.5. Subsequently, using deuterated FA (DCOOD) and $\mathrm{D}_{2} \mathrm{O}$, the rate-determining step differed, depending on the position of the $\mathrm{OH}$ substituent because of the kinetic isotope effect (KIE). In FADH, it is speculated that the reaction proceeds through the following three elementary reactions: (i) formation of the formato complex by the reaction of the catalyst precursor and formate ion, (ii) formation of the Ir-H complex by the $\beta$-elimination of $\mathrm{CO}_{2}$, and (iii) hydrogen production by reaction of the $\mathrm{Ir}-\mathrm{H}$ complex and a proton. The estimated rate-determining step (RDS) of Ir-1 was (iii) by KIE experiments, while the considered RDS of Ir-2 was (ii), owing to the pendant-base effect of the $\mathrm{OH}$ groups near the metal (Figure 5). This consideration is supported by the DFT calculations. 


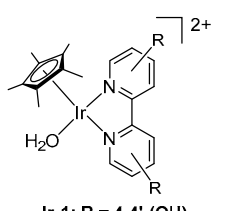

$\mathrm{r}-1: \mathrm{R}=4, \mathbf{4}^{-}-(\mathrm{OH})_{2}$

Ir-2: $R=6,6^{\prime}-(\mathrm{OH})_{2}$

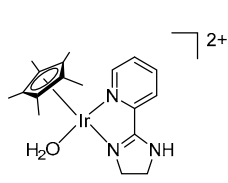

Ir-7
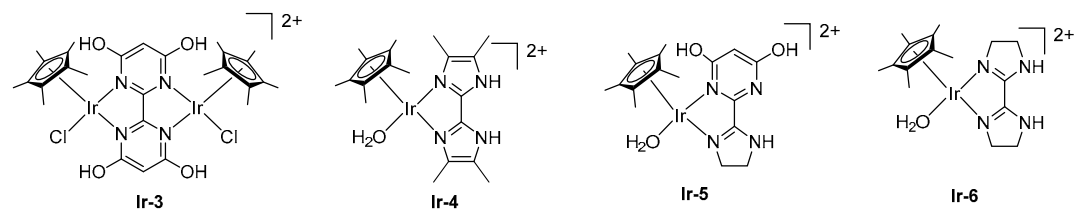

Ir-6
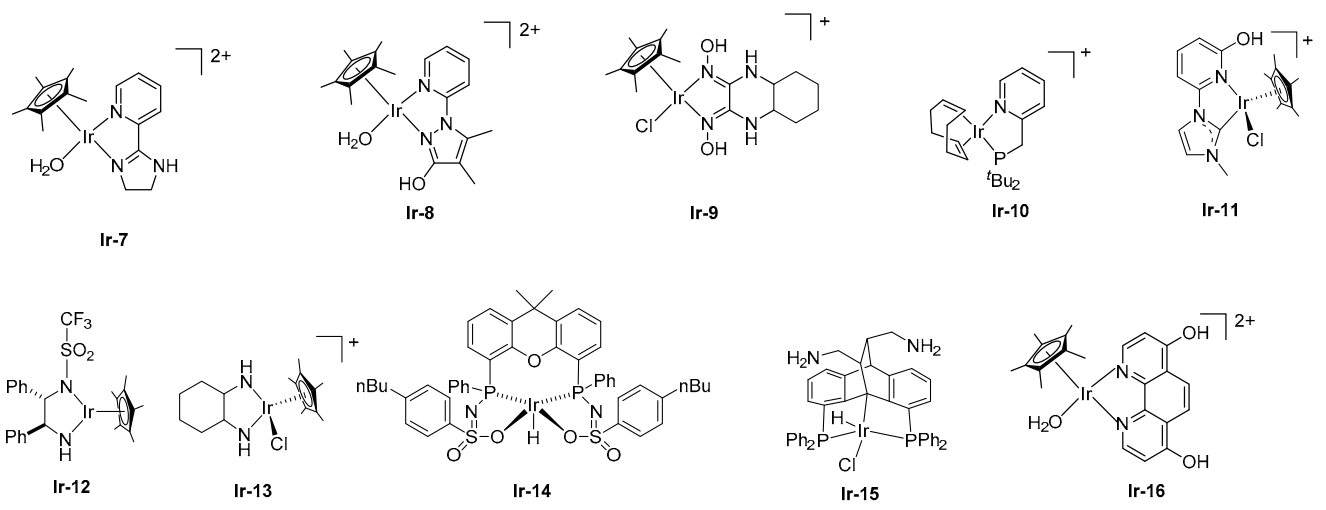

Figure 4. Ir catalysts for FADH.

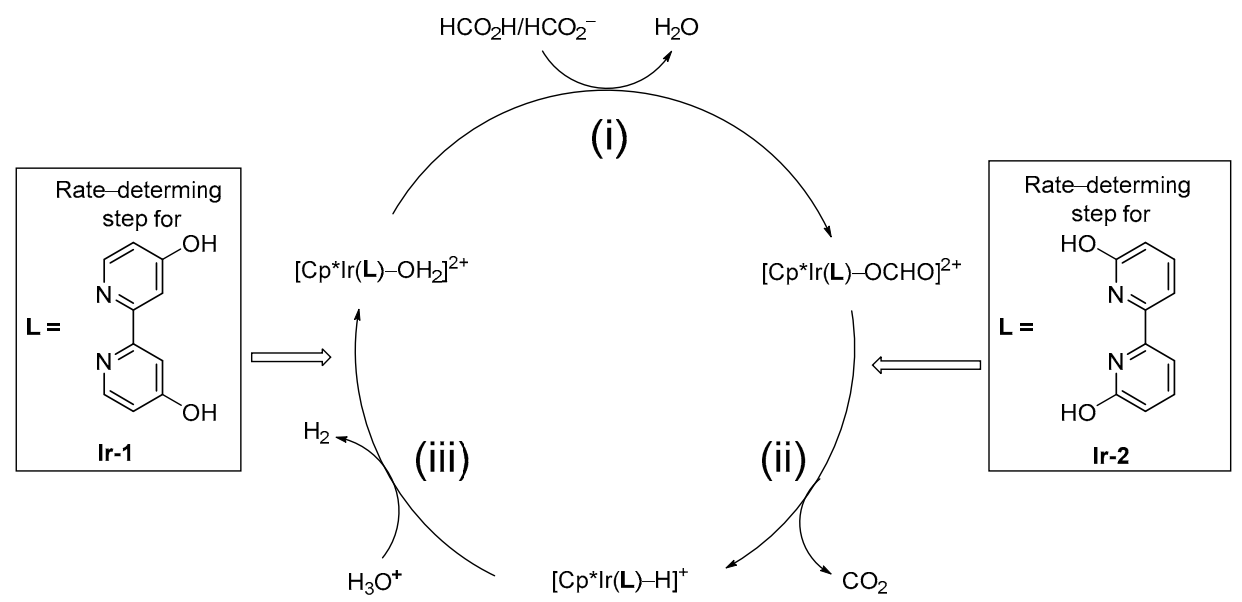

Figure 5. Proposed mechanism and different rate-determining steps of Ir-1 and Ir-2 [19].

Ir catalysts bearing THBPM (THBPM $=2,2^{\prime}, 6,6^{\prime}$-tetrahydroxyl-4,4'-bipyrimidine) (Ir-3), which has four $\mathrm{OH}$ groups on the ligand, showed high catalytic activity with a TOF of $158,000 \mathrm{~h}^{-1}$ and TON of 308,000 in a $1 \mathrm{M}$ aqueous FA/ $\mathrm{HCO}_{2} \mathrm{Na}$ (SF) solution at $80{ }^{\circ} \mathrm{C}$ [20]. Because Ir-3 also demonstrated high performance for the hydrogenation of $\mathrm{CO}_{2}$ to formate, a reverse reaction of $\mathrm{FADH}$, it was possible to perform the interconversion of $\mathrm{CO}_{2} / \mathrm{FA}$. It was proved that both hydrogen storage and hydrogen generation reactions could be performed in one batch by performing both cycles twice.

Subsequently, Himeda et al. reported that an Ir catalyst-bearing a five-membered ring, such as imidazole or imidazoline, could be an effective ligand bone. Tetramethyl biimidazole was an effective ligand framework in the C ${ }^{*}$ Ir catalyst (Ir-4), which exhibited a TOF of 34,000 $\mathrm{h}^{-1}$ [21]. Furthermore, they synthesized an imidazoline-based ligand for the first time, using a combination of dihydroxypyrimidine (Ir-5) [22]. Ir-5 exhibited a high TOF of $322,000 \mathrm{~h}^{-1}$ with a TON of 68,000 , under reflux conditions in $4 \mathrm{M}$ FA/SF. Furthermore, a C ${ }^{*}$ Ir catalyst-bearing an azole-based ligand with hydroxy pyrimidine reached a high TON in $6 \mathrm{M}$ FA at $60^{\circ} \mathrm{C}(\mathrm{TON}=2,000,000)$. Independently, Li et al. developed a novel Ir complex, bearing a bisimidazoline ligand (Ir-6), which showed the highest catalytic activity in water, with a TOF of $487,500 \mathrm{~h}^{-1}$ [32]. The pyridyl-imidazoline ligand was also effective for FADH [23]. Although Ir-7 demonstrated lower catalytic activity than Ir-6, its robustness was remarkably improved, due to the combination of a robust pyridyl moiety 
and active imidazoline moiety. Furthermore, FADH catalyzed by Ir-7 was performed in $1 \mathrm{~L}$ of a $10 \mathrm{M}$ FA solution at $50^{\circ} \mathrm{C}$ to produce a large volume of $\mathrm{H}_{2}$. After the consumption of approximately $80 \%$ of the loaded FA, an additional $10 \mathrm{~mol}$ of FA was added. Finally, the reaction was completed with the generation of $1 \mathrm{~m}^{3}$ of gas, without critical deactivation. However, Ir-7 was deactivated under reflux conditions (conditions: $[\mathrm{FA}]=8.0 \mathrm{M}, 100 \mathrm{~mL}$, [cat] $=10 \mu \mathrm{M}$, at $110^{\circ} \mathrm{C}$ ). Conversely, Ir-8 completely consumed FA, even under reflux conditions [24]. Additionally, Ir-8 maintained its catalytic activity during a long-term reaction ( $35 \mathrm{~d}$ ), with the continuous addition of FA using a pump (Figure 6). Finally, a total TON of 10 million was achieved, as well as the evolved gas volume of $2.5 \mathrm{~m}^{3}$, which was the highest to be reported. Subsequently, Li et al. employed a glyoxime ligand as a new ligand framework [25]. Using a novel Cp* Ir catalyst (Ir-9) in a $10 \mathrm{M}$ FA solution at $90^{\circ} \mathrm{C}$, they achieved a high TON of 3,900,000 and average TOF of $65,000 \mathrm{~h}^{-1}$.

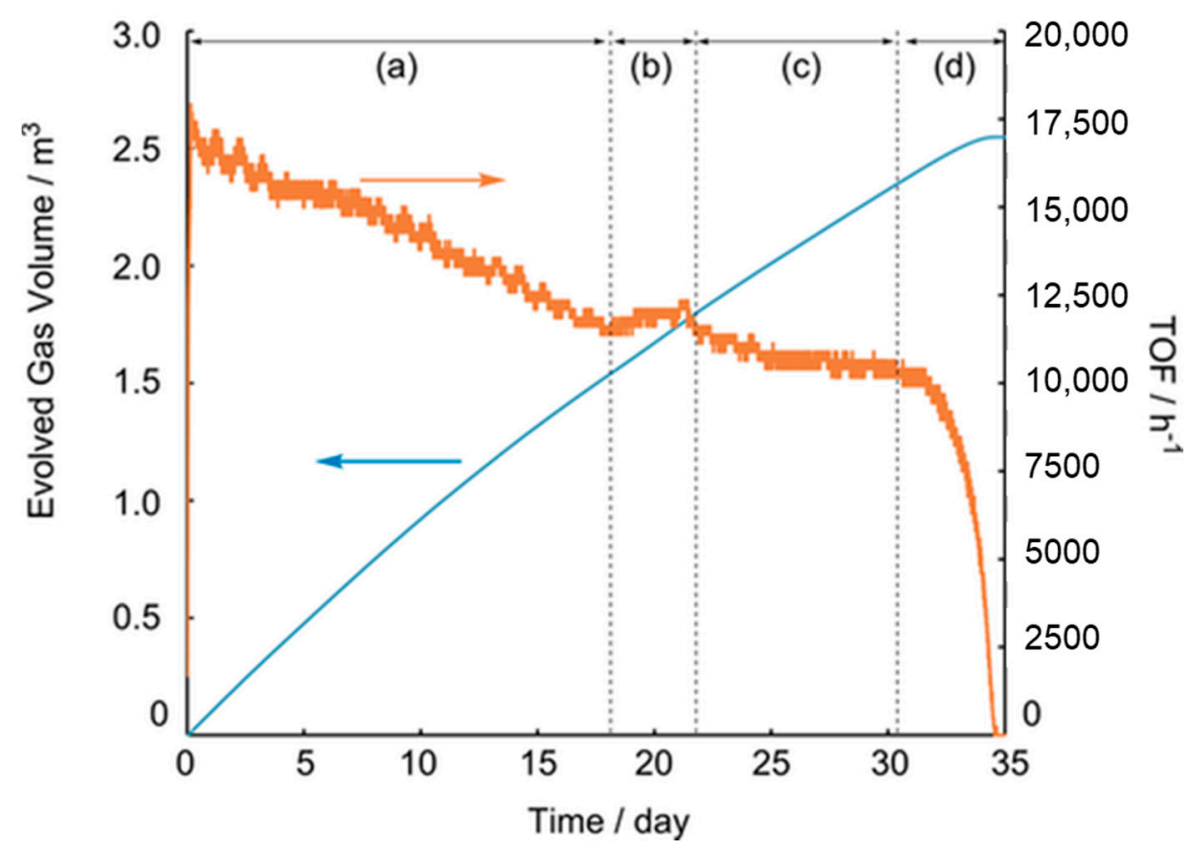

Figure 6. Time courses of volume of released gases (blue line) and rate of gas release (orange line) in FADH, with the continuous addition of FA by a pump. Conditions: $[\mathrm{FA}]_{0}=4.0 \mathrm{M}, 500 \mathrm{~mL}$, $[\mathrm{Ir}-8]_{0}=10 \mu \mathrm{M},[\mathrm{FA}]_{\mathrm{add}}=80 \mathrm{wt} \%(=20 \mathrm{M})$, at $70{ }^{\circ} \mathrm{C}$. Rate of FA addition: $(\mathbf{a})=0.07 \mathrm{~mL} / \mathrm{min}, 420 \mathrm{~h}$, $35.3 \mathrm{~mol},(\mathbf{b})=$ stop, $(\mathbf{c})=0.05 \mathrm{~mL} / \mathrm{min}, 250 \mathrm{~h}, 15 \mathrm{~mol},(\mathbf{d})=$ stop, total FA amount = $52.3 \mathrm{~mol}$ [24]; (c) 2022 Wiley.

Williams et al. reported that FADH was catalyzed by the Ir catalyst Ir-10, which bears a pyridyl phosphine ligand converted to the active dimeric species via the elimination of a cyclooctadiene moiety [26]. Remarkably, this catalysis could proceed without any solvent in a neat FA solution. In addition, the neat FA could be utilized without purification for this reaction. In the presence of HCOONa as a cocatalyst (5 $\mathrm{mol} \%$ ), a TON of 12,530 was obtained at $90^{\circ} \mathrm{C}$ after $13 \mathrm{~h}$. Furthermore, a pale orange residue, composed of an iridium complex and $\mathrm{HCOONa}$, remained in the reaction vessel after the completion of the reaction, which was reused for the next neat FADH. Therefore, the reaction was restarted by feeding neat FA into the reaction vessel at $90^{\circ} \mathrm{C}$, without other operations to regenerate the catalyst. Notably, repeated experiments resulted in a TON of 2,160,000 and TOF of $3.7 \mathrm{~s}^{-1}$. According to the GC measurement, the gas obtained from this reaction consisted only $\mathrm{H}_{2}$ and $\mathrm{CO}_{2}$ and contained almost no detectable CO. Papish et al. reported NHC as an effective ligand framework in C ${ }^{*}$ Ir catalyst (Ir-11) for FADH [27]. The NHC moiety in the ligand was expected to form a stable metal-ligand bond, owing to its high electron-donating ability. However, the catalytic performance of the complex did not reach the same level as that of the other $\mathrm{Cp}^{*} \mathrm{Ir}$ catalysts with an $\mathrm{N}^{\wedge} \mathrm{N}$-bidentate ligand. Ikariya et al. investigated the 
Cp*Ir complex with N-triflyl-1,2-diphenylethylenediamine (Ir-12) for FADH at ambient temperature without base additives [28]. Particularly, the isolation of the Ir-H complex, a reaction intermediate generated by the reaction of Ir-12 with FA, showed that the catalytic activity for FADH was almost similar to that of the original complex. Moreover, the addition of water improved the catalytic activity, leading to a maximum TOF above $6000 \mathrm{~h}^{-1}$. A proton relay mechanism, guided by the protic amine ligand and water, was postulated for the effective protonation of the metal hydrides. Laurenczy et al. investigated various non-aromatic diamine-type ligands for $\mathrm{Cp}^{*}$ Ir-catalyzed $\mathrm{FADH}$, which demonstrated high catalytic activity in water without any organic amines [29]. In particular, the complex bearing 1,2-diaminocyclohexane (Ir-13) achieved the highest performance, with a TOF of $3300 \mathrm{~h}^{-1}$ at $90{ }^{\circ} \mathrm{C}$. In general, many effective ligands for $\mathrm{C} \mathrm{p}^{*} \mathrm{Ir}$ catalysts for FADH are aromatic rings, such as pyridine. Therefore, the aforementioned results obtained for nonaromatic diamine-type ligands were significant for developing new ligands. Reek et al. reported an Ir catalyst (Ir-14) with a bisMETAMORPhos ligand that has an internal base functionality [30]. In this catalytic system, introducing an electron-donating substituent into sulfonamide enhanced the catalytic activity (up to a TOF of $3090 \mathrm{~h}^{-1}$ ) at $85^{\circ} \mathrm{C}$. NMR and computational studies suggested that the hydrogen bonding interactions between FA and the ligand contributed to the stabilization of intermediates and transition states, leading to an unusual direct hydride transfer mechanism, instead of the conventional $\beta$-hydride elimination for FADH. In 2017, Gelman et al. reported a new bi-functional Ir catalyst, bearing PCP ligand for FADH [31]. Ir-15 achieved a TON of up to 500,000 and a TOF of $20,000 \mathrm{~h}^{-1}$ in DME at $70{ }^{\circ} \mathrm{C}$ in the presence of $30 \mathrm{~mol} \%$ HCOONa. From experimental and mechanistic studies, hydrogen is liberated through intramolecular protonolysis of the $\mathrm{Ir}-\mathrm{H}$ bond and the formation of a cationic species stabilized by the amine chelation from the amino group in the backbone. Regeneration of the active intermediate was performed via an outer-sphere intramolecular $\beta$-H elimination of $\mathrm{CO}_{2}$.

In $\mathrm{FADH}$, it is necessary to remove $\mathrm{CO}_{2}$ gas from the mixed gas to provide highly purified $\mathrm{H}_{2}$ for fuel cell vehicles. Thermodynamically, FADH proceeds, even at high pressures under mild temperatures, owing to entropy changes during the reaction $\left(\mathrm{G}^{\circ}=-32.9 \mathrm{~kJ} / \mathrm{mol}\right)$. The pressurization and subsequent FADH into $\mathrm{H}_{2}$ avoids the consumption of $\mathrm{H}_{2}$ compression energy. For purification, FADH was allowed to proceed in a closed vessel. Kawanami et al. found that Ir-16 was involved in FADH under evolved $\mathrm{H}_{2} / \mathrm{CO}_{2}$ pressures of up to $123 \mathrm{MPa}$ at $80^{\circ} \mathrm{C}$ [34-36]. Under the reaction conditions, the generated gas mixture was in the supercritical phase; therefore, it allowed $\mathrm{H}_{2}$ purification via a simple reduction of the temperature. Cooling to $-51{ }^{\circ} \mathrm{C}$ separated the two phases, that is a $\mathrm{CO}_{2}$-rich liquid and $85 \mathrm{~mol} \%$ pure $\mathrm{H}_{2}$ gas phase. They concluded that the $\mathrm{H}_{2}$ release from FA in this manner could sufficiently feed a fuel cell vehicle that typically stores a high-purity carrier at $70 \mathrm{MPa}$, thus avoiding the need for a costly high-pressure pump.

\section{Non-Precious Metal Catalysts for FADH}

Precious metals are often used as the central metal for highly active catalysts. However, the development of inexpensive metal catalysts is essential, due to the possibility of resource depletion. Although several non-precious metal catalysts for FADH have been reported, they exhibit low catalytic activity. However, various non-precious metal catalysts, including iron [37-39], nickel, cobalt [40,41], copper [42], and aluminum [43,44], have also been recently reported. The following is a summary of the recent notable achievements (Figure 7 , Table 2). 

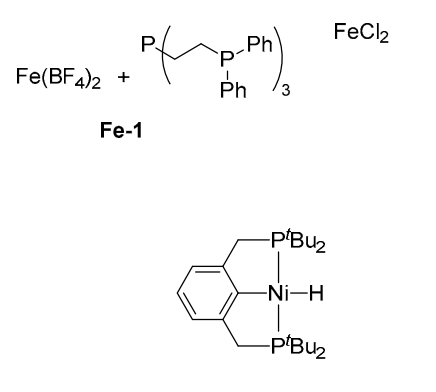

$\mathrm{Ni}-1$

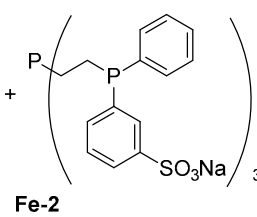

Fe-2

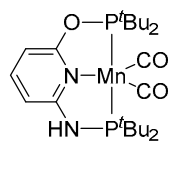

$\mathrm{Mn}-1$

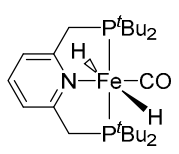

$\mathrm{Fe}-3$

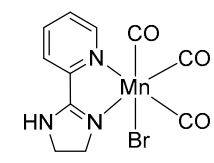

$\mathrm{Mn}-2$

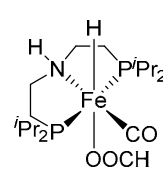

$\mathrm{Fe}-4$
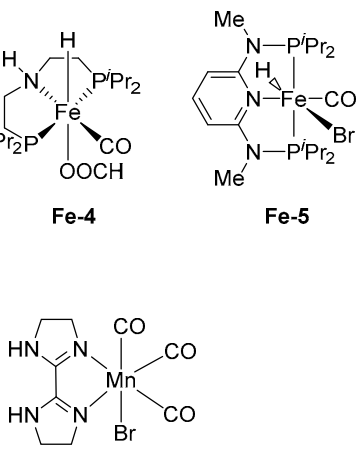

$\mathrm{Mn}-3$

Figure 7. Non-precious metal catalysts for FADH.

Table 2. Selected non-precious metal catalysts for FADH.

\begin{tabular}{|c|c|c|c|c|c|c|}
\hline Catalyst & Temp., ${ }^{\circ} \mathrm{C}$ & Solvent & Additive & TON & TOF, $h^{-1}$ & Ref. \\
\hline Fe-1 & 80 & PC & - & 92,000 & 5390 & [45] \\
\hline $\mathrm{Fe}-2$ & 80 & $\mathrm{H}_{2} \mathrm{O}$ & - & - & 240 & [46] \\
\hline $\mathrm{Fe}-3$ & 40 & dioxane & $\mathrm{NEt}_{3}$ & 100,000 & - & [47] \\
\hline $\mathrm{Fe}-4$ & 80 & dioxane & $\mathrm{LiBF}_{4}$ & $1,000,000$ & 196,700 & [48] \\
\hline $\mathrm{Fe}-5$ & 80 & PC & $\mathrm{NEt}_{3}$ & 10,000 & 2635 & [49] \\
\hline $\mathrm{Fe}-6$ & 60 & PC & - & 6061 & - & [50] \\
\hline $\mathrm{Ni}-1$ & 80 & PC & $\mathrm{OctNMe}_{2}$ & 626 & 209 & [51] \\
\hline $\mathrm{Ni}-2$ & 80 & $\mathrm{C}_{6} \mathrm{D}_{6}$ & - & 70 & 1.7 & [52] \\
\hline Mn-1 & 80 & chlorobenzene & $\mathrm{NEt}_{3}$ & 20,000 & 8500 & [53] \\
\hline Mn-2 & 92.5 & $\mathrm{H}_{2} \mathrm{O}$ /triglyme & $\mathrm{KOH}$ & 5763 & - & [54] \\
\hline Mn-3 & 95 & DMOA & - & 7500 & - & [55] \\
\hline
\end{tabular}

In 2011, an important paper on iron catalysts was reported by Beller et al. [45]. Particularly, $\mathrm{Fe}\left(\mathrm{BF}_{4}\right)_{2} \cdot 6 \mathrm{H}_{2} \mathrm{O}$ was employed for the catalytic $\mathrm{FADH}$, in the presence of a tetradentate tris[2-(diphenylphosphino)ethyl]phosphine (tetraphos, $\mathrm{PP}_{3}$ ) ligand with high activity (Fe-1). The Fe/PP3 system converted all of the FA to generate $\mathrm{H}_{2} / \mathrm{CO}_{2}(1 / 1)$ without the CO byproduct $(<1 \mathrm{ppm})$ at $40{ }^{\circ} \mathrm{C}$. A high TOF $\left(9425 \mathrm{~h}^{-1}\right)$ was obtained at $80^{\circ} \mathrm{C}$, with a low catalyst loading $(0.005 \mathrm{~mol} \%)$ and Fe/PP3 (1/4). Additionally, the stability of this catalytic system was examined. FA was continuously added to the catalytic solution $(\mathrm{Fe} / 4 \mathrm{PP} 3)$ via a pump $\left(0.27 \pm 0.04 \mathrm{~mL} \mathrm{~min}^{-1}\right)$, and the reaction was observed. Remarkably, a stable TOF $\left(5390 \mathrm{~h}^{-1}\right)$ was obtained over $16 \mathrm{~h}$, and the total TON reached 92,000 . Subsequently, they reported the results of a detailed investigation of the effect of various ligands, metal salts, solvents, and additives [56]. A decrease in the catalytic activity was observed when water was added. The DFT calculations and spectroscopic investigations (IR, Raman, UV-vis, and XAS) identified the iron $\eta^{2}$-formate $\left[\mathrm{Fe}\left(\eta^{2}-\mathrm{O}_{2} \mathrm{CH}\right)(\mathrm{PP} 3)\right]$ as the key active species for the catalytic reaction. However, this active species was deactivated in the presence of chloride ions. Subsequently, Laurenczy et al. investigated an aqueous iron catalyst system for FADH, using $\mathrm{FeCl}_{2}$ and water-soluble $m$-trisulfonated-tris[2-(diphenylphosphino)ethyl]phosphine sodium salt as a PP3 derivative $(\mathbf{F e}-2)$ at $80{ }^{\circ} \mathrm{C}$ [46]. The catalytic system was active for FADH, with a TOF of up to $240 \mathrm{~h}^{-1}$. The gases produced were CO-free $(<5 \mathrm{ppm})$. In addition, the catalytic system was recycled four times, without any significant loss of activity.

Catalysts bearing the pincer-type ligands have also been extensively studied for FADH. In 2013, Milstein et al. reported that the Fe PNP-pincer complex (Fe-3) trans$\left[\mathrm{Fe}(t \mathrm{BuPNP})(\mathrm{H})_{2}(\mathrm{CO})\right](0.001 \mathrm{~mol} \%)$ catalyzed $\mathrm{FADH}$ in the presence of $50 \mathrm{~mol}^{\circ} \mathrm{NEt}_{3}$ in dioxane, with a TON of 100,000 at $40{ }^{\circ} \mathrm{C}$ [47]. This catalyst exhibited excellent stability and maintained its catalytic performance for $10 \mathrm{~d}$. Experimental studies revealed that the catalytic process proceeded via protonation of the iron dihydride catalyst, followed by the liberation of dihydrogen and conversion of unsaturated species to the hydrido-formate complex. Regeneration of the iron hydride catalyst was achieved via $\mathrm{CO}_{2}$ elimination. 
Hazari et al. reported that the catalytic activity of a Fe complex (Fe-4) bearing a PNP-pincer ligand, $[(\mathrm{PNP}) \mathrm{Fe}(\mathrm{CO}) \mathrm{H}(\mathrm{COOH})]\left(\mathrm{PNP}=\mathrm{HN}\left[\mathrm{C}_{2} \mathrm{H}_{4}\left(\mathrm{PiPr}_{2}\right)\right]_{2}\right)$, improved in the presence of a Lewis acid as a cocatalyst $[48,57]$. FADH was achieved using this iron catalyst $(0.0001 \mathrm{~mol} \%)$, in the presence of $\mathrm{LiBF}_{4}(10 \mathrm{~mol} \%)$ in dioxane at $80{ }^{\circ} \mathrm{C}$, with a high TOF of $196,700 \mathrm{~h}^{-1}$ and a TON of 1,000,000 in $9.5 \mathrm{~h}$. They proposed that Lewis acids assisted in the decarboxylation of the Fe-formate intermediate to generate the Fe-hydride complex (Figure 8).

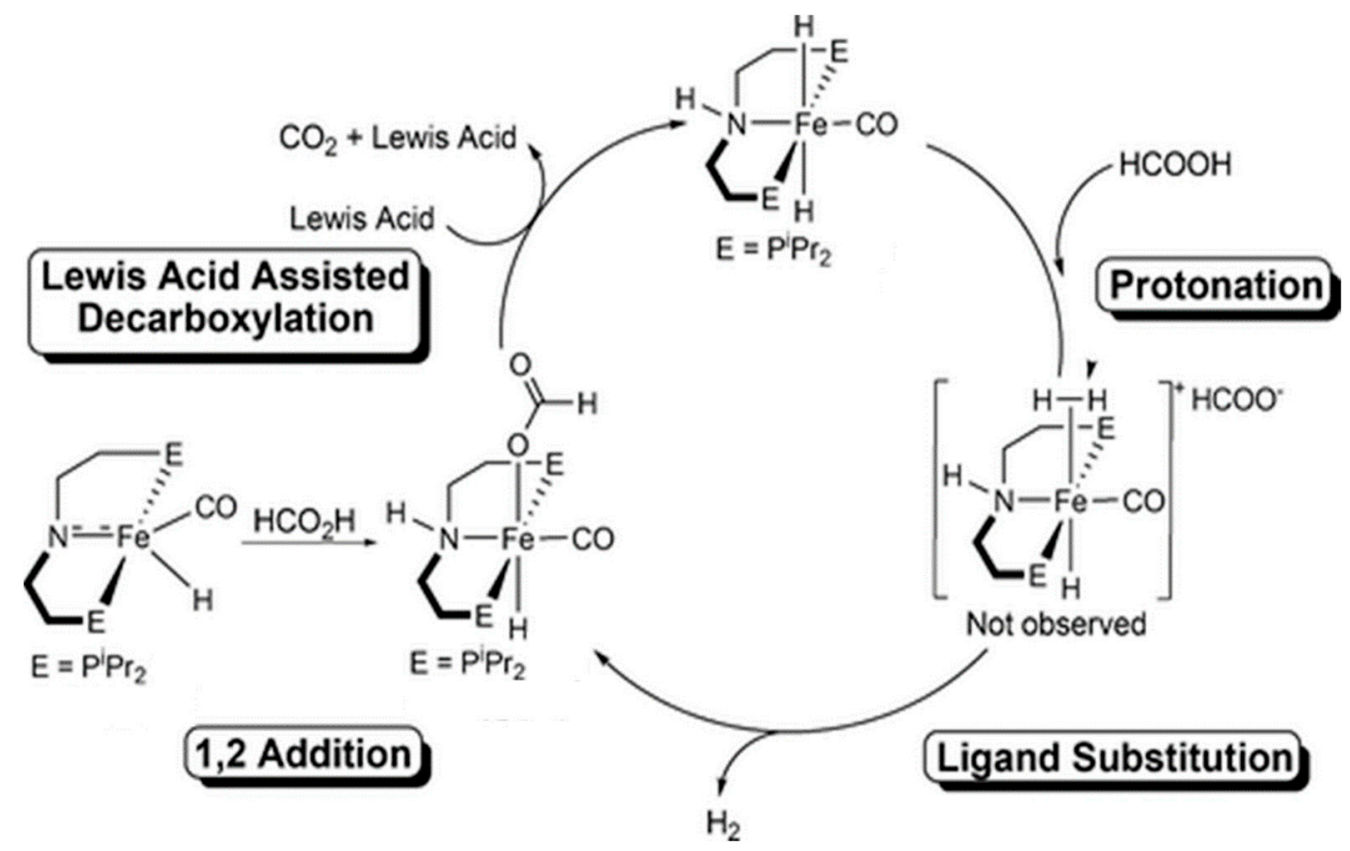

Figure 8. Proposed reaction mechanism for FADH catalyzed by Fe-4 in the presence of a Lewis acid [48] @ ACS 2014.

Gonsalvi et al. investigated an effective Fe complex (Fe-5)-bearing 2,6-diaminopyridine as a PNNNP pincer ligand for FADH. No reactions were observed in the absence of a base [49]. However, adding a base, such as $\mathrm{NEt}_{3}(50 \mathrm{~mol} \%)$, improved the catalytic activity, with a TOF of $276 \mathrm{~h}^{-1}$ at $60{ }^{\circ} \mathrm{C}$. FADH, using this catalyst in propylene carbonate (PC), with $\mathrm{NEt}_{3}$ at $80{ }^{\circ} \mathrm{C}$, yielded a TON of 10,000 and TOF of $2635 \mathrm{~h}^{-1}$, with the complete consumption of FA. Further, the authors investigated the role of amines, using NMR experiments, and found that the amines released $\mathrm{Br}$ and promoted the regeneration of the reaction intermediate. Gonsalvi et al. also reported that the tetraphos ligand P4 (Figure 3) was effective for iron-catalyzed FADH. This linear tetraphos ligand could have two isomers, meso- or rac-(Fe-6) [50]. The catalytic activity of the rac-isomer was higher than that of the meso isomer. It was also found that the ratio of Fe to the tetraphos ligand has a significant influence on the catalytic activity, as 1 to 4 showed higher catalytic activity than 1 and 2 . FADH could proceed in PC at $60^{\circ} \mathrm{C}$, with a TON of 6061 , without any additives such as a base; the reaction was catalyzed by in-situ-generated Fe-6, using rac-P4 with $\mathrm{Fe}\left(\mathrm{BF}_{4}\right)_{2} \cdot 6 \mathrm{H}_{2} \mathrm{O}$ $(\mathrm{Fe} /$ Ligand $=1 / 4)$.

Nickel can also be used as a catalyst. Enthaler found that a Ni catalyst (Ni-1) with a PCP pincer ligand catalyzes FADH [51]. First, in the presence of FA and $\mathrm{NEt}_{3}, \mathrm{NMR}$ experiments confirmed that FA reacts with the hydride moiety in the Ni complex and FA is completely consumed. Subsequently, when FADH was performed for $2 \mathrm{~h}$ in PC, using a Ni catalyst with $n \mathrm{OctNMe}_{2}$ as an additive, a TON of 481 was obtained, and a small amount of $\mathrm{CO}$ was produced. In addition, the catalyst could be reused by adding fresh FA after the completion of the reaction. Notably, the reused catalyst has almost similar catalytic activity, as in the first-stage reaction. Inspired by the work of Enthaler et al., Parkin et al. reported on the zerovalent $\mathrm{Ni}$ complex $\mathrm{Ni}\left(\mathrm{PMe}_{3}\right)_{4}(\mathrm{Ni}-2)$, which showed catalytic activity toward FADH, with a TON of 80 and TOF of $1.7 \mathrm{~h}^{-1}$ [52]. Reaction intermediate was observed 
by ${ }^{1} \mathrm{H}$ NMR experiments, and it was clarified that the starting material reacted with FA to generate a hydride complex, $\left[\mathrm{Ni}\left(\mathrm{PMe}_{3}\right)_{4} \mathrm{H}\right]+$.

Recently, it has been reported that manganese was used as a catalyst for FADH. In 2019, Tondreau et al. found that $\left[(t \mathrm{BuPNNOP}) \mathrm{Mn}(\mathrm{CO})_{2}\right] \mathrm{Br}(\mathbf{M n}-\mathbf{1})$ achieved FADH, with a TOF of $8500 \mathrm{~h}^{-1}$ and TON of 20,000, in the presence of $\mathrm{NEt}_{3}$ and chlorobenzene at $80{ }^{\circ} \mathrm{C}$ [53]. The authors also proved that $\mathbf{M n - 1}$ was robust toward FADH and could be recycled five times. In 2020, Beller et al. showed that imidazoline-based ligand was effective for manganesecatalyzed FADH $[54,55]$. A Mn-2-bearing pyridyl-imidazoline ligand converted FA to generate $14 \mathrm{~L}$ of $\mathrm{H}_{2} / \mathrm{CO}_{2}$ mixture gases (TON of 5736) and was stable for more than $3 \mathrm{~d}$ in the presence of $\mathrm{KOH}$ in $\mathrm{H}_{2} \mathrm{O}$ /triglyme solution. It was found that the catalyst performance of $\mathbf{M n}-\mathbf{2}$ deteriorated as the $\mathrm{pH}$ rose with the consumption of FA. Therefore, the catalytic performance could be maintained by adding a buffer to maintain a neutral $\mathrm{pH}$. Additionally, it was clarified that another Mn catalyst (Mn-3), using an imidazoline derivative as a ligand, was effective for FADH, with a TON of 7500 and a small amount of $\mathrm{CO}$ contamination $(<50 \mathrm{ppm})$ in DMOA at $95^{\circ} \mathrm{C}$.

\section{Conclusions}

FA is less toxic under ambient conditions and has a flash point well above room temperature, as well as a hydrogen content of $4.4 \mathrm{wt} \%$, making it one of the most promising materials for hydrogen storage. Today, many highly active and robust homogeneous catalysts that selectively decompose FA into $\mathrm{H}_{2}$ and $\mathrm{CO}_{2}$ have been developed and elucidated in the literature. Particularly, catalysts that exhibit good performance in organic solvents and water have been developed. In addition, there are catalysts whose catalytic activity and durability have been evaluated, implying that studies on practical applications are imminent. Moreover, the development of effective catalysts that exhibits catalytic activity toward the hydrogenation of $\mathrm{CO}_{2}$ to FA or formate is progressing, in order to reduce $\mathrm{CO}_{2}$ in the atmosphere. Some of the catalysts introduced in this paper currently are also effective for $\mathrm{CO}_{2}$ hydrogenation, and it is expected that the transition to a hydrogen society will be accelerated by combining these well.

It was found that precious metals had higher catalytic performance than non-precious metals. However, the research to improve the catalytic performance of non-precious metals remains vital, considering the cost of the catalysts. It is also important to improve the durability of the catalyst for practical use. A system that stably supplies hydrogen at a constant rate, without deactivating during the reaction, is required. In addition, because hydrogen generated from FA contains $\mathrm{CO}_{2}$, it is essential to take measures for removing $\mathrm{CO}_{2}$. Although Kawanami et al. attempted to increase the pressure in a sealed state, a low temperature was required. In the future, it will be important to increase the purity of hydrogen, with minimum wastage of energy [58].

Author Contributions: Writing—original draft preparation, N.O.; writing—review and editing, R.K., H.K. and Y.H. All authors have read and agreed to the published version of the manuscript.

Funding: This work was supported by JSPS KAKENHI Grant number 20K05593.

Institutional Review Board Statement: Not applicable.

Informed Consent Statement: Not applicable.

Data Availability Statement: All data are included at the manuscript.

Conflicts of Interest: The authors declare no conflict of interest.

\section{References}

1. Schlapbach, L.; Züttel, A. Hydrogen-storage materials for mobile applications. Nature 2001, 414, 353-358. [CrossRef]

2. Aziz, M.; Wijayanta, A.T.; Nandiyanto, A.B.D. Ammonia as Effective Hydrogen Storage: A Review on Production, Storage and Utilization. Energies 2020, 13, 3062. [CrossRef]

3. Akbayrak, S.; Özkar, S. Ammonia borane as hydrogen storage materials. Int. J. Hydrogen Energy 2018, 43, 18592-18606. [CrossRef] 
4. Sordakis, K.; Tang, C.; Vogt, L.K.; Junge, H.; Dyson, P.J.; Beller, M.; Laurenczy, G. Homogeneous Catalysis for Sustainable Hydrogen Storage in Formic Acid and Alcohols. Chem. Rev. 2018, 118, 372-433. [CrossRef]

5. Joó, F. Breakthroughs in Hydrogen Storage-Formic Acid as a Sustainable Storage Material for Hydrogen. ChemSusChem 2008, 1, 805-808. [CrossRef]

6. Onishi, N.; Iguchi, M.; Yang, X.; Kanega, R.; Kawanami, H.; Xu, Q.; Himeda, Y. Development of Effective Catalysts for Hydrogen Storage Technology Using Formic Acid. Adv. Energy Mater. 2019, 9, 1801275. [CrossRef]

7. Coffey, R.S. The decomposition of formic acid catalysed by soluble metal complexes. Chem. Commun. 1967, 18, 923b-924. [CrossRef]

8. Paonessa, R.S.; Trogler, W.C. Solvent-dependent reactions of carbon dioxide with a platinum(II) dihydride. Reversible formation of a platinum(II) formatohydride and a cationic platinum(II) dimer, $\left[\mathrm{Pt}_{2} \mathrm{H}_{3}\left(\mathrm{PEt}_{3}\right)_{4}\right]\left[\mathrm{HCO}_{2}\right]$. J. Am. Chem. Soc. 1982, 104, 3529-3530. [CrossRef]

9. Laine, R.M.; Rinker, R.G.; Ford, P.C. Homogeneous catalysis by ruthenium carbonyl in alkaline solution: The water gas shift reaction. J. Am. Chem. Soc. 1977, 99, 252-253. [CrossRef]

10. Strauss, S.H.; Whitmire, K.H.; Shriver, D.F. Rhodium(I) catalyzed decomposition of formic acid. J. Organomet. Chem. 1979, 174, C59-C62. [CrossRef]

11. Loges, B.; Boddien, A.; Junge, H.; Beller, M. Controlled Generation of Hydrogen from Formic Acid Amine Adducts at Room Temperature and Application in $\mathrm{H}_{2} / \mathrm{O}_{2}$ Fuel Cells. Angew. Chem. Int. Ed. 2008, 47, 3962-3965. [CrossRef]

12. Fellay, C.; Dyson, P.J.; Laurenczy, G. A Viable Hydrogen-Storage System Based On Selective Formic Acid Decomposition with a Ruthenium Catalyst. Angew. Chem. Int. Ed. 2008, 47, 3966-3968. [CrossRef]

13. Piccirilli, L.; Lobo Justo Pinheiro, D.; Nielsen, M. Recent Progress with Pincer Transition Metal Catalysts for Sustainability. Catalysts 2020, 10, 773. [CrossRef]

14. Pan, Y.; Pan, C.-L.; Zhang, Y.; Li, H.; Min, S.; Guo, X.; Zheng, B.; Chen, H.; Anders, A.; Lai, Z.; et al. Selective Hydrogen Generation from Formic Acid with Well-Defined Complexes of Ruthenium and Phosphorus-Nitrogen PN ${ }^{3}$-Pincer Ligand. Chem. Asian J. 2016, 11, 1357-1360. [CrossRef]

15. Mellone, I.; Bertini, F.; Peruzzini, M.; Gonsalvi, L. An active, stable and recyclable Ru(ii) tetraphosphine-based catalytic system for hydrogen production by selective formic acid dehydrogenation. Catal. Sci. Technol. 2016, 6, 6504-6512. [CrossRef]

16. Guan, C.; Zhang, D.-D.; Pan, Y.; Iguchi, M.; Ajitha, M.J.; Hu, J.; Li, H.; Yao, C.; Huang, M.-H.; Min, S.; et al. Dehydrogenation of Formic Acid Catalyzed by a Ruthenium Complex with an N,N'-Diimine Ligand. Inorg. Chem. 2017, 56, 438-445. [CrossRef]

17. Kar, S.; Rauch, M.; Leitus, G.; Ben-David, Y.; Milstein, D. Highly efficient additive-free dehydrogenation of neat formic acid. Nat. Catal. 2021, 4, 193-201. [CrossRef]

18. Himeda, Y. Highly efficient hydrogen evolution by decomposition of formic acid using an iridium catalyst with 4,4 [prime or minute]-dihydroxy-2,2[prime or minute]-bipyridine. Green Chem. 2009, 11, 2018-2022. [CrossRef]

19. Wang, W.-H.; Xu, S.; Manaka, Y.; Suna, Y.; Kambayashi, H.; Muckerman, J.T.; Fujita, E.; Himeda, Y. Formic Acid Dehydrogenation with Bioinspired Iridium Complexes: A Kinetic Isotope Effect Study and Mechanistic Insight. ChemSusChem 2014, 7, 1976-1983. [CrossRef] [PubMed]

20. Hull, J.F.; Himeda, Y.; Wang, W.-H.; Hashiguchi, B.; Periana, R.; Szalda, D.J.; Muckerman, J.T.; Fujita, E. Reversible hydrogen storage using $\mathrm{CO}_{2}$ and a proton-switchable iridium catalyst in aqueous media under mild temperatures and pressures. Nat. Chem. 2012, 4, 383-388. [CrossRef]

21. Manaka, Y.; Wang, W.-H.; Suna, Y.; Kambayashi, H.; Muckerman, J.T.; Fujita, E.; Himeda, Y. Efficient $\mathrm{H}_{2}$ generation from formic acid using azole complexes in water. Catal. Sci. Technol. 2014, 4, 34-37. [CrossRef]

22. Wang, W.-H.; Ertem, M.Z.; Xu, S.; Onishi, N.; Manaka, Y.; Suna, Y.; Kambayashi, H.; Muckerman, J.T.; Fujita, E.; Himeda, Y. Highly Robust Hydrogen Generation by Bioinspired Ir Complexes for Dehydrogenation of Formic Acid in Water: Experimental and Theoretical Mechanistic Investigations at Different pH. ACS Catal. 2015, 5, 5496-5504. [CrossRef]

23. Onishi, N.; Ertem, M.Z.; Xu, S.; Tsurusaki, A.; Manaka, Y.; Muckerman, J.T.; Fujita, E.; Himeda, Y. Direction to practical production of hydrogen by formic acid dehydrogenation with $\mathrm{Cp}{ }^{*}$ Ir complexes bearing imidazoline ligands. Catal. Sci. Technol. 2016, 6, 988-992. [CrossRef]

24. Onishi, N.; Kanega, R.; Fujita, E.; Himeda, Y. Carbon Dioxide Hydrogenation and Formic Acid Dehydrogenation Catalyzed by Iridium Complexes Bearing Pyridyl-pyrazole Ligands: Effect of an Electron-donating Substituent on the Pyrazole Ring on the Catalytic Activity and Durability. Adv. Synth. Catal. 2019, 361, 289-296. [CrossRef]

25. Lu, S.-M.; Wang, Z.; Wang, J.; Li, J.; Li, C. Hydrogen generation from formic acid decomposition on a highly efficient iridium catalyst bearing a diaminoglyoxime ligand. Green Chem. 2018, 20, 1835-1840. [CrossRef]

26. Celaje, J.J.A.; Lu, Z.; Kedzie, E.A.; Terrile, N.J.; Lo, J.N.; Williams, T.J. A prolific catalyst for dehydrogenation of neat formic acid. Nat. Commun. 2016, 7, 11308. [CrossRef]

27. Siek, S.; Burks, D.B.; Gerlach, D.L.; Liang, G.; Tesh, J.M.; Thompson, C.R.; Qu, F.; Shankwitz, J.E.; Vasquez, R.M.; Chambers, N.; et al. Iridium and Ruthenium Complexes of N-Heterocyclic Carbene- and Pyridinol-Derived Chelates as Catalysts for Aqueous Carbon Dioxide Hydrogenation and Formic Acid Dehydrogenation: The Role of the Alkali Metal. Organometallics 2017, 36, 1091-1106. [CrossRef] 
28. Matsunami, A.; Kayaki, Y.; Ikariya, T. Enhanced Hydrogen Generation from Formic Acid by Half-Sandwich Iridium(III) Complexes with Metal/NH Bifunctionality: A Pronounced Switch from Transfer Hydrogenation. Chem. Eur. J. 2015, 21, 13513-13517. [CrossRef] [PubMed]

29. Fink, C.; Laurenczy, G. $\mathrm{CO}_{2}$ as a hydrogen vector-Transition metal diamine catalysts for selective $\mathrm{HCOOH}$ dehydrogenation. Dalton Trans. 2017, 46, 1670-1676. [CrossRef] [PubMed]

30. Oldenhof, S.; Lutz, M.; de Bruin, B.; Ivar van der Vlugt, J.; Reek, J.N.H. Dehydrogenation of formic acid by Ir-bisMETAMORPhos complexes: Experimental and computational insight into the role of a cooperative ligand. Chem. Sci. 2015, 6, 1027-1034. [CrossRef] [PubMed]

31. Cohen, S.; Borin, V.; Schapiro, I.; Musa, S.; De-Botton, S.; Belkova, N.V.; Gelman, D. Ir(III)-PC(sp $\left.{ }^{3}\right)$ P Bifunctional Catalysts for Production of $\mathrm{H}_{2}$ by Dehydrogenation of Formic Acid: Experimental and Theoretical Study. ACS Catal. 2017, 7, 8139-8146. [CrossRef]

32. Wang, Z.; Lu, S.-M.; Li, J.; Wang, J.; Li, C. Unprecedentedly High Formic Acid Dehydrogenation Activity on an Iridium Complex with an N,N'-Diimine Ligand in Water. Chem. Eur. J. 2015, 21, 12592-12595. [CrossRef]

33. Suna, Y.; Ertem, M.Z.; Wang, W.-H.; Kambayashi, H.; Manaka, Y.; Muckerman, J.T.; Fujita, E.; Himeda, Y. Positional Effects of Hydroxy Groups on Catalytic Activity of Proton-Responsive Half-Sandwich Cp*Iridium(III) Complexes. Organometallics 2014, 33, 6519-6530. [CrossRef]

34. Iguchi, M.; Himeda, Y.; Manaka, Y.; Kawanami, H. Development of an Iridium-Based Catalyst for High-Pressure Evolution of Hydrogen from Formic Acid. ChemSusChem 2016, 9, 2749-2753. [CrossRef] [PubMed]

35. Iguchi, M.; Himeda, Y.; Manaka, Y.; Matsuoka, K.; Kawanami, H. Simple Continuous High-Pressure Hydrogen Production and Separation System from Formic Acid under Mild Temperatures. ChemCatChem 2016, 8, 886-890. [CrossRef]

36. Iguchi, M.; Zhong, H.; Himeda, Y.; Kawanami, H. Effect of the ortho-Hydroxyl Groups on a Bipyridine Ligand of Iridium Complexes for the High-Pressure Gas Generation from the Catalytic Decomposition of Formic Acid. Chem. Eur. J. 2017, 23, 17788-17793. [CrossRef]

37. Boddien, A.; Gärtner, F.; Jackstell, R.; Junge, H.; Spannenberg, A.; Baumann, W.; Ludwig, R.; Beller, M. ortho-Metalation of Iron(0) Tribenzylphosphine Complexes: Homogeneous Catalysts for the Generation of Hydrogen from Formic Acid. Angew. Chem. Int. Ed. 2010, 49, 8993-8996. [CrossRef] [PubMed]

38. Yang, X. Mechanistic insights into iron catalyzed dehydrogenation of formic acid: $\beta$-hydride elimination vs. direct hydride transfer. Dalton Trans. 2013, 42, 11987-11991. [CrossRef]

39. Wang, L.; Sun, H.; Zuo, Z.; Li, X.; Xu, W.; Langer, R.; Fuhr, O.; Fenske, D. Activation of $\mathrm{CO}_{2}, \mathrm{CS}_{2}$, and Dehydrogenation of Formic Acid Catalyzed by Iron(II) Hydride Complexes. Eur. J. Inorg. Chem. 2016, 2016, 5205-5214. [CrossRef]

40. Zhou, W.; Wei, Z.; Spannenberg, A.; Jiao, H.; Junge, K.; Junge, H.; Beller, M. Cobalt-Catalyzed Aqueous Dehydrogenation of Formic Acid. Chem. Eur. J. 2019, 25, 8459-8464. [CrossRef]

41. Lentz, N.; Aloisi, A.; Thuéry, P.; Nicolas, E.; Cantat, T. Additive-Free Formic Acid Dehydrogenation Catalyzed by a Cobalt Complex. Organometallics 2021, 40, 565-569. [CrossRef]

42. Scotti, N.; Psaro, R.; Ravasio, N.; Zaccheria, F. A new Cu-based system for formic acid dehydrogenation. RSC Adv. 2014, 4 , 61514-61517. [CrossRef]

43. Myers, T.W.; Berben, L.A. Aluminium-ligand cooperation promotes selective dehydrogenation of formic acid to $\mathrm{H}_{2}$ and $\mathrm{CO}_{2}$. Chem. Sci. 2014, 5, 2771-2777. [CrossRef]

44. Lu, Q.-Q.; Yu, H.-Z.; Fu, Y. Computational Study of Formic Acid Dehydrogenation Catalyzed by AlIII-Bis(imino)pyridine Chem. Eur. J. 2016, 22, 4584-4591. [CrossRef]

45. Boddien, A.; Mellmann, D.; Gärtner, F.; Jackstell, R.; Junge, H.; Dyson, P.J.; Laurenczy, G.; Ludwig, R.; Beller, M. Efficient Dehydrogenation of Formic Acid Using an Iron Catalyst. Science 2011, 333, 1733-1736. [CrossRef] [PubMed]

46. Montandon-Clerc, M.; Dalebrook, A.F.; Laurenczy, G. Quantitative aqueous phase formic acid dehydrogenation using iron(II) based catalysts. J. Catal. 2016, 343, 62-67. [CrossRef]

47. Zell, T.; Butschke, B.; Ben-David, Y.; Milstein, D. Efficient Hydrogen Liberation from Formic Acid Catalyzed by a Well-Defined Iron Pincer Complex under Mild Conditions. Chem. Eur. J. 2013, 19, 8068-8072. [CrossRef]

48. Bielinski, E.A.; Lagaditis, P.O.; Zhang, Y.; Mercado, B.Q.; Würtele, C.; Bernskoetter, W.H.; Hazari, N.; Schneider, S. Lewis Acid-Assisted Formic Acid Dehydrogenation Using a Pincer-Supported Iron Catalyst. J. Am. Chem. Soc. 2014, 136, 10234-10237. [CrossRef]

49. Mellone, I.; Gorgas, N.; Bertini, F.; Peruzzini, M.; Kirchner, K.; Gonsalvi, L. Selective Formic Acid Dehydrogenation Catalyzed by Fe-PNP Pincer Complexes Based on the 2,6-Diaminopyridine Scaffold. Organometallics 2016, 35, 3344-3349. [CrossRef]

50. Bertini, F.; Mellone, I.; Ienco, A.; Peruzzini, M.; Gonsalvi, L. Iron(II) Complexes of the Linear rac-Tetraphos-1 Ligand as Efficient Homogeneous Catalysts for Sodium Bicarbonate Hydrogenation and Formic Acid Dehydrogenation. ACS Catal. 2015, 5, 1254-1265. [CrossRef]

51. Enthaler, S.; Brück, A.; Kammer, A.; Junge, H.; Irran, E.; Gülak, S. Exploring the Reactivity of Nickel Pincer Complexes in the Decomposition of Formic Acid to $\mathrm{CO}_{2} / \mathrm{H}_{2}$ and the Hydrogenation of $\mathrm{NaHCO}_{3}$ to $\mathrm{HCOONa}$. ChemCatChem 2015, 7, 65-69. [CrossRef]

52. Neary, M.C.; Parkin, G. Nickel-catalyzed release of $\mathrm{H}_{2}$ from formic acid and a new method for the synthesis of zerovalent $\mathrm{Ni}\left(\mathrm{PMe}_{3}\right)_{4}$. Dalton Trans. 2016, 45, 14645-14650. [CrossRef] 
53. Anderson, N.H.; Boncella, J.; Tondreau, A.M. Manganese-Mediated Formic Acid Dehydrogenation. Chem. Eur. J. 2019, 25, 10557-10560. [CrossRef]

54. Léval, A.; Agapova, A.; Steinlechner, C.; Alberico, E.; Junge, H.; Beller, M. Hydrogen production from formic acid catalyzed by a phosphine free manganese complex: Investigation and mechanistic insights. Green Chem. 2020, 22, 913-920. [CrossRef]

55. Léval, A.; Junge, H.; Beller, M. Manganese(i) $\mathrm{k}^{2}-\mathrm{NN}$ complex-catalyzed formic acid dehydrogenation. Catal. Sci. Technol. 2020, 10, 3931-3937. [CrossRef]

56. Mellmann, D.; Barsch, E.; Bauer, M.; Grabow, K.; Boddien, A.; Kammer, A.; Sponholz, P.; Bentrup, U.; Jackstell, R.; Junge, H.; et al Base-Free Non-Noble-Metal-Catalyzed Hydrogen Generation from Formic Acid: Scope and Mechanistic Insights. Chem. Eur. J. 2014, 20, 13589-13602. [CrossRef] [PubMed]

57. Curley, J.B.; Smith, N.E.; Bernskoetter, W.H.; Hazari, N.; Mercado, B.Q. Catalytic Formic Acid Dehydrogenation and CO 2 Hydrogenation Using Iron PNRP Pincer Complexes with Isonitrile Ligands. Organometallics 2018, 37, 3846-3853. [CrossRef]

58. Filonenko, G.A.; van Putten, R.; Schulpen, E.N.; Hensen, E.J.M.; Pidko, E.A. Highly Efficient Reversible Hydrogenation of Carbon Dioxide to Formates Using a Ruthenium PNP-Pincer Catalyst. ChemCatChem 2014, 6, 1526-1530. [CrossRef] 